\title{
Complement Component Protein
}

National Cancer Institute

\section{Source}

National Cancer Institute. Complement Component Protein. NCI Thesaurus. Code C21523.

Any of the serum proteins that interact with antigen antibody complex to produce cytolytic, chemotaxic, anaphylactic, and other effects. (from CSP2000) 